\title{
Mental health and immigration detention
}

\author{
The detrimental effects of prolonged closed detention underscore the need for \\ alternative arrangements
}

Gillian Triggs

LLB, LLM, PhD, Presiden

Australian Human Rights Commission, Sydney, NSW.

president.ahrc@ humanrights.gov.au

doi: 10.5694/mjal3.11369

Perspective $\mathrm{p} 730$ Research p 776 ccurate, objective information about the quality of health care services in immigration detention centres has never been more important than it is today, with thousands of asylum seekers and refugees, including children, detained. ${ }^{1}$

In this issue of the Journal, two articles bring research rigour to assessing the prevalence of psychiatric morbidity and self-harm and suicide among asylum seekers held in detention. In the first, Deans and colleagues describe the incidence of mental illness specifically among asylum seekers treated at the Royal Darwin Hospital emergency department. ${ }^{2}$ It concludes that health care services at regional immigration detention centres are deficient and that mental illness is the most common reason for presentation to the hospital. In the second, more broadly, Procter and colleagues consider the May 2013 report by the Commonwealth and Immigration Ombudsman into suicide and self-harm across the Australian immigration detention network, confirming that "Mental distress and despair are clinical correlates of being held in detention" ${ }^{3}$ The authors usefully suggest implementing strategies to monitor the mental health of detainees and collect meaningful data on self-harm and suicide.

The Australian Human Rights Commission welcomes this research and supports the recommendations. The Commission has long been concerned by the mounting evidence that the mandatory detention of unlawful noncitizens by the Australian Government under the Migration Act 1958 (Cwlth) has led to significant deterioration in the mental health of asylum seekers and refugees. As of 30 September 2013, there were 6403 people in closed detention, including 1078 children. ${ }^{4}$ It is not surprising, in light of these high detention rates, that between January 2011 and February 2013 there were 4313 reported incidents of actual, threatened and attempted serious self-harm in immigration detention facilities. ${ }^{5}$ Between 1 July 2010 and 20 June 2013, there were 12 deaths in immigration detention. Coroners have found that six of these deaths were suicides.

In its 2004 report on the national inquiry into children in immigration detention, the Commission found that children held in immigration detention for long periods were at high risk of serious mental harm. ${ }^{1}$ More recently, the Commission has raised concerns for the wellbeing of unaccompanied minors who were held in Pontville Alternative Place of Detention, Tasmania (some 358 minors on 19 August 2013). Between 1 January 2013 and 14 August 2013 , there were reports of 50 incidents of actual self-harm and 49 incidents of threatened self-harm at Pontville Alternative Place of Detention. This information was provided to the Commission by the Department of Immigration and Citizenship (now Department of Immigration and Border Protection) in September 2013.

These figures on self-harm confirm the Commission's concerns that mandatory and indefinite detention has a detrimental impact on the mental health of detainees. Mental health problems of asylum seekers who are detained range from depression, anxiety and sleep disorders to post-traumatic stress disorder, suicidal ideation and self-harm.

The Commission is responsible for monitoring Australia's compliance with its international human rights obligations. It is of domestic and international significance that, in August 2013, the Human Rights Committee of the United Nations found that the indefinite detention of 46 refugees who had received adverse security assessments was "inflicting serious psychological harm" which amounted to cruel, inhuman or degrading treatment. ${ }^{6,7}$ This was not the first such finding. The Human Rights Committee has previously found Australia to be in breach of the right not to be subjected to cruel, inhuman or degrading treatment or punishment, and the right of detainees to be treated with dignity, by continuing to detain people in the knowledge that it was contributing to mental illness. 8,9

Some improvements in the delivery of mental health services to immigration detention facilities should be acknowledged. Since 2011, steps have been taken by the Department of Immigration and Citizenship to strengthen the Psychological Support Program and the new Programs and Activities Framework. ${ }^{5}$ Many medical professionals have observed, nonetheless, that it is often the detention environment itself that causes mental illness. Accordingly, it is the removal of people from closed detention that will have the most powerful effect in mitigating mental illness.

The Commission has long recommended that the Australian Government increase the use of community detention and bridging visas to reduce the numbers of asylum seekers in closed detention. In the 2012-13 financial year, $88 \%$ of asylum seekers who had arrived by boat and lodged asylum applications were found to be refugees and were granted permanent residency in Australia. ${ }^{10}$ It therefore makes much better sense, and is more humane, to adopt these strategies to ensure that asylum seekers can lead healthy lives in the future. 
Competing interests: No relevant disclosures.

Provenance: Commissioned; not externally peer reviewed.

1 Human Rights and Equal Opportunity Commission. A last resort? National inquiry into children in immigration detention. Sydney: HREOC, 2004. http://www.humanrights.gov.au/sites/default/files/content/human_rights/ children_detention_report/report/PDF/alr_complete.pdf (accessed Nov 2013)

2 Deans AK, Boerma CJ, Fordyce J, et al. Use of Royal Darwin Hospital emergency department by immigration detainees in 2011. Med J Aust 2013; 199: 776-778.

3 Procter NG, De Leo D, Newman L. Suicide and self-harm prevention for people in immigration detention. Med J Aust 2013; 199: 730-732.

4 Department of Immigration and Border Protection. Immigration detention and community statistics. http://www.immi.gov.au/About/Pages/aboutimmigration-detention.aspx?heading=immigration-detention-andcommunity-statistics (accessed Nov 2013).

5 Commonwealth and Immigration Ombudsman. Suicide and self-harm in the immigration detention network. Canberra: Commonwealth Ombudsman, 2013.http://www.ombudsman.gov.au/files/suicide_and_self-harm_in_the_ immigration_detention_network.pdf (accessed Nov 2013).

6 United Nations Human Rights Committee. F K A G et al v Australia. 2013, paragraphs 9.4 and 9.8. (Communication No. 2094/2011; UN Doc. CCPR/C/ 108/D/2094/2011.)

7 United Nations Human Rights Committee. M M M et al v Australia. 2013, paragraphs 10.4 and 10.7. (Communication No. 2136/2012; UN Doc. CCPR/C/ 108/D/2136/2012.)

8 United Nations Human Rights Committee. C v Australia. 2002, paragraph 10. (Communication No. 900/1999; UN Doc. CCPR/C/76/D/900/1999.)

9 United Nations Human Rights Committee. Madafferi v Australia. 2004, paragraph 9.3. (Communication No. 1011/2001; UN Doc. CCPR/C/81/D/1011/ 2001.)

10 Department of Immigration and Border Protection. Asylum trends - Australia 2012-13. Canberra: DIBP, 2013. http://www.immi.gov.au/media/publications/ statistics (accessed Dec 2013). 